
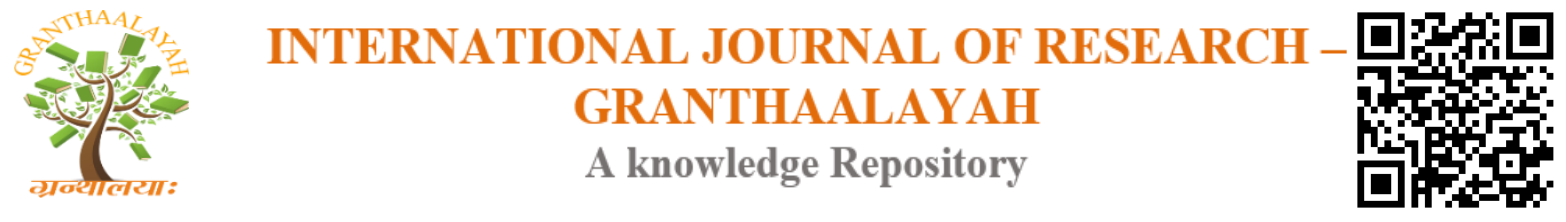

Social

\title{
VERSATILITY THY NAME IS AAMIR KHAN: THEMATIC STUDY OF THREE SELECTED FILMS
}

\author{
Afaq Ahmad *1 \\ ${ }^{1}$ Research Scholar, Department of Mass Communication, Aligarh Muslim University, Aligarh- \\ 202 002, (Uttar Pradesh), India
}

\begin{abstract}
Hindi cinema has acquired a universal identity in Indian society as it is one of the most popular forms of entertainment, education and information in India. As purveyor of entertainment, Bollywood has provided a platform to many actors to flourish their talents as an actor. As far as Aamir Khan is concerned, acting is the life, blood, and soul of Aamir Khan. The way he portrays various characters in his movies, make him a perfect actor of versatile genre. Less studies have been conducted on Aamir Khan and his movies, and on the versatile portrayal of Aamir Khan contained in his movies. The purpose of this paper is to understand the versatile characteristics played by Aamir Khan in his movies. The present paper makes an attempt to critically analyse the three movies of different genres of Aamir Khan. These movies were purposively selected as Lagaan - a patriotic, productional and nostalgic movie, Rang De Basanti - a revolutionary, nationalistic and rebellious movie, and Taare Zameen Par - an inspirational, experimental and directorial movie, on account of their distinguishing stories. As the selected films etched a niche in the hearts and minds of cinemagoers and movie viewers due to their innovative stories and splendid cinematography, the thematic analysis was undertaken. It has been found from the study that message-oriented aspects depicted in these movies. Further, the informative, inspirational, patriotic, reformative, and revolutionary characteristics predominantly glimpsed in his movies. The versatile characteristics of Aamir Khan was also meticulously scrutinized. It has been found after having a critical analysis that Aamir Khan has versatile characteristics as depicted in these three selected movies under study.
\end{abstract}

Keywords: Aamir Khan's Movies; Critical Analysis; Bollywood Films; Versatile Actor.

Cite This Article: Afaq Ahmad. (2019). "VERSATILITY THY NAME IS AAMIR KHAN: THEMATIC STUDY OF THREE SELECTED FILMS." International Journal of Research Granthaalayah, 7(4), 213-224. https://doi.org/10.29121/granthaalayah.v7.i4.2019.893.

\section{Introduction}

"My passion for my work shows on screen...I thoroughly enjoy the work I do." - Aamir Khan Aamir Khan known as a perfectionist in the Bollywood cinema scenario. He is a well accomplished actor who gives his soul to work. Though, he has a family background related to the Hindi Cinema 
yet there is just no wrong in saying that it is his true talent and hard work that has earned him the place which he rests on today. Aamir Khan is a name which needs no recognition. He is one among the few Indian film personalities having the distinction of being an actor, producer, director, screenplay writer, occasional singer on his own right, and the founder-owner of a successful venture called Aamir Khan Productions (AKP).

Aamir Khan first began his film career as a child actor in a home production, produced and directed by Nasir Hussain, titled Yaadon Ki Baraat (1973) and Madhosh (1974). Eleven years later, he made his adult acting debut in a role that went quite unnoticed in Ketan Mehta's Holi (1984). Khan's first notable leading role came in 1988 in the film as a teenybopper heart-throb in Qayamat Se Qayamat Tak which was directed by his cousin and Nasir Hussain's son Mansoor Khan. Qayamat Se Qayamat Tak was a breakthrough success at the box office, effectively launching Khan's career as a leading actor. Having the typical 'chocolate hero' looks, he was publicised as a teen idol. After that, he went on to appear in several other films in the late ' 80 s and early '90s: Dil (1990), which became the highest grossing film of the year, Dil Hai Ke Manta Nahin (1991), Jo Jeeta Wohi Sikandar (1992), Hum Hain Rahi Pyar Ke (1993) (for which he also wrote the screenplay), and Rangeela (1995). Most of these films were successful both critically and commercially (Rajadhyaksha \& Willemen, 1999).

Aamir Khan founded his own production company, Aamir Khan Productions, to help finance his longtime friend Ashutosh Gowariker's dream of making the film Lagaan. The movie was released in 2001, starring Khan as the lead actor. The film was a major critical and commercial success, and was selected as India's official entry to the $74^{\text {th }}$ Academy Awards in the Best Foreign Language Film category. It was eventually chosen and nominated in that category along with four other foreign films, but lost to No Man's Land. Additionally, the film gathered critical acclaim at several international film festivals, apart from winning numerous Bollywood awards, including National Film Awards. Khan himself won his second Filmfare Best Actor Award and commented on loss of Lagaan at the Oscars, saying, "Certainly we were disappointed. But the thing that really kept us in our spirits was that the entire country was behind us."

Rakesh Omprakash Mehra's award-winning, Rang De Basanti, was Khan's first release in 2006. His role was critically acclaimed, earning him a Filmfare Critics Award for Best Performance and various nominations for Best Actor. The film went on to become one of the highest grossing films of the year, and was selected as India's official entry to the Oscars. Although the film was not shortlisted as a nominee, it received a nomination for Best Foreign Film at the BAFTA Awards in England.

His 2007 film, Taare Zameen Par (about a teacher who befriends and helps a dyslexic child), which Khan produced and also starred in, marked his directorial debut. The film, which was the second offering from Aamir Khan Productions, opened to excellent responses from critics and audiences alike. His work won him two awards at the Filmfare, the Best Movie and the Best Director awards, and established his status as a competent director and a story-teller. Being a part of several commercially successful movies and delivering highly acclaimed performances, he established himself as one of the leading actors of Hindi cinema. 
Khan continued to act in just one or two films a year, an unusual trait for a mainstream Hindi Cinema actor. An important aspect of Aamir's success is the fact that he has thrived on carefully chosen characters and films, but has never worked with the likes of Mani Ratnam, Subhash Ghai, or even David Dhawan. Instead, he has backed unknown names such as Ashutosh Gowarikar ('Baazi') and John Matthew Mathan ('Sarfarosh') and even a flop filmmaker like Vikram Bhatt.

\section{Aamir Khan - The Versatile Actor}

You don't see him often. But, when you do, he always manages to create ripples...not only at the box-office, but also in the minds of his diehard fans. This groovy actor, who prefer to lay down his own set of rules has carved himself a niche in the world of Bollywood, using both his talent and brain. The man who was awarded Padma Bhushan for the year 2003 by the Government of India goes by the philosophy 'one at a time.' All his films have a gap of one, two or more years, unlike other actors.

Aamir is one of the few actors who have acted in all genres of Indian films-comedy, action, drama and romance. Though he performs in few films, Aamir Khan is acknowledged today as the most complete Indian actor for his diverse choice of roles and films.

Aamir Khan is choosy while deciding to act, produce or direct a movie. He himself asserted that "I don't look at a film from the point of view of a role. The script has to come first. What I look for in a director is the fact that he's talented, has to know his tools, and has leadership qualities. Making a film is like war. You have to lead from the front. What's most important is - does the director have a story to tell? Is there something bursting to come out of him?"

\section{Review of Literature}

The material for the study, particularly of the study of Aamir Khan's profile and his personality depicting him as a versatile actor has been largely drawn from the newspapers, magazines, online journals and other sources. In order to have it I did not shy away from consulting the morgue for the purpose of the study, particularly of Aamir Khan's viewpoint on subjects like patriotism, secularism and heroism, the researcher has referred to certain papers published online or otherwise have been referred to, prominent among them are:

1) Frontline, by Dionne Bunsha, June 03-16, 2006.

2) The Hindu, by Zia-Us-Salam, and Rana Siddiqui, July 11, 2008.

3) The Times of India, by Anshul Chaturvedi, July 09, 2008.

4) The Times of India, Kalpana Sharma, and Jyothi Prabhakar, July 12, 2008.

In order to study the films that are included in the work for the purpose of establishing Aamir Khan as a versatile personality, a broad study of the film reviews and previews was also referred to from Encyclopedia of Indian Cinema and other sources. Some pieces of articles that draw a fine picture of Aamir Khan's period and his growing impact on Indian cinema forms the basic foundations of the study.

\section{Aims and Objectives of the Study}

The aim of the study is to critically analyse the selected movies of Aamir Khan, having versatile characteristics emerged in his characters on the screen. Whereas the objective is based upon how 
Aamir Khan has been proved his versatility from all fronts through the various multiplified characters in his movies. The specific objectives of the study contain:

- To verify the presumption that Aamir Khan is a perfectionist, having a versatile genre in his characters on the silver screen;

- To find out the specific contributions of Aamir Khan's films to the development of Indian cinema, especially creative innovations of the art form by critically analysing his films;

- To find out the effects of Aamir Khan's movies on Bollywood and future implications.

\section{Importance of the Study}

During the over hundred years of its existence, the Indian film industry has seen many ups and downs, passed through several importance stages and a number of people have contributed to this growth and have added glorious chapters to the history of Indian cinema. Some have immensely contributed to rescue the art form during crises while some others have contributed to enrich it through their creative talents and have set new benchmarks for the industry to move forward. A study of these landmarks will undoubtedly help in its future growth and its further enrichment. This study intends to analyze the portrayal of Aamir Khan in different roles in Indian cinema and his contributions to Indian cinema. It attempts to critically analyze the various portrayals of Aamir Khan on the basis of his selected movies. Further, it is aimed at assessing the manner in which Aamir Khan played different roles in different categories, three films out of a large number of movies of Aamir Khan were selected. The study also attempts to determine the way in which Aamir Khan's films affect his image of versatility.

\section{Hypothesis}

1) “Lagaan”, "Rang De Basanti and "Taare Zameen Par" has immortalised Aamir Khan's image as a versatile actor.

2) His directional venture - Taare Zameen Par has left an indelible impact on the hearts and minds of viewers, opponents and critics.

3) Aamir Khan played a vital role to evoke patriotic sense in his movies like Lagaan, and Rang De Basanti by playing the role of Bhuvan and DJ respectively.

\section{Research Methodology}

The methodology adopted in the study is the Content Analysis of the most prominent and crucial Hindi films of Aamir Khan depicting him in multiple characters on silver screen. For the content analysis, three films of Aamir Khan were purposively chosen from different genres and versatile portrayal of Aamir Khan in different roles. The criterion behind the selection of the films has been their versatile portrayal on the silver screen. All the selected movies of Aamir Khan highlight him as a perfectionist of versatile genre.

Selection of three films out of the lot was the only subtle ways to deal with, in view of the time and resources available at hand. In order to have an in-depth analysis of the movies under review, the most effective method was to watch the movies and observe the portrayal of Aamir Khan's versatile character to make a qualitative assessment of his films. The findings have been interpreted 
to draw meaningful conclusions in the context of the Indian film industry in general and Aamir Khan in particular.

\section{Thematic study of the three selected films of Aamir Khan}

\section{Lagaan, a patriotic, productional and nostalgic movie}

Lagaan is set in late 19th century India. The movie got Filmfare Critics Award for Best Movie in 2002.

Captain Andrew Russell (Paul Blackthorne), the commanding officer of a British cantonment, oppresses the people of Champaner with high taxes (lagaan). The local ruler, Rajah Pooran Singh, asks that taxes be lowered, to ease the suffering of the drought-stricken villagers. Captain Russell humiliates the Rajah by asking him to eat meat if he wishes the taxes to be lowered. The Rajah, who was a vegetarian by religion, says that he must keep the rules of his religion and his caste; he cannot eat meat. Captain Russell then doubles the taxes. The peasants, who are already suffering from a prolonged drought, are devastated by this news. The monsoon is late; they will be unable to pay regular taxes, much less double taxes. They beg the Rajah to help them, but he says he cannot persuade the British to mercy. The villagers, returning from their fruitless audience with the Rajah, stop to watch the British officers playing cricket. Captain Russell notices them and sees the young, impetuous Bhuvan (Aamir Khan), who has previously angered him. The captain offers Bhuvan a wager: He will cancel the taxes of the whole province for three years if the villagers can beat his men at cricket. If they lose, they will owe triple tax. To the horror of the other villagers, Bhuvan accepts this wager on their behalf. Later, he explains that as they can pay neither double nor triple taxes, they should grab the chance for a tax remission.

Bhuvan (Aamir Khan) raises his voice against the oppressive taxation. Nonetheless, the villagers of Champaner, and of all the neighboring villages, are furious with Bhuvan. No one has ever played cricket. How can complete novices beat the British?

Upon learning of Captain Russell's wager, his superiors in the British Army admonish him for his arrogant and irresponsible behaviour. They tell him that if he loses the match, he will have to reimburse all the taxes from his own pocket and moreover suffer a transfer to Central Africa. Led by the courageous Bhuvan and helped by Russell's good-hearted sister Elizabeth (Rachel Shelley), a few villagers begin to learn cricket. As time progresses, more and more villagers are convinced to join Bhuvan's team. The villagers have eccentric self-styled techniques-Goli swings his arms many times before releasing the ball, while Bhura, the chicken farmer organises fielding training for the other villagers by having them attempt to catch his hens.

In the end, Bhuvan has ten volunteers, one less than the eleven needed for a cricket team. Bhuvan finds his final player by chance, after the village cripples and untouchable Kachra inadvertently demonstrates his ability to bowl leg spin while returning the ball to the players. However, the village head and other members of the team threaten to quit the team, refusing to play with an untouchable. Bhuvan responds with an impassioned speech in front of the village, chastising everyone for their discrimination, after which they agree to allow Kachra to take his place in the team. 
As they spend time together, Elizabeth falls in love with Bhuvan, who is himself attached to a charming local girl, Gauri (Gracy Singh). Though Bhuvan feels nothing but respect for Elizabeth and Elizabeth ever expresses her feelings, Gauri sees how matters stand and is anxious until Bhuvan declares his love. This infuriates the woodcutter Lakha, who had hoped to win Gauri himself.

Bhuvan (Aamir Khan) with an eclectic mix of the village-folk forming their cricket team. Lakha decides to humble Bhuvan by forcing him to lose the match. Lakha joins the team, but secretly meets with Captain Russell, informing him of everything that is happening. The captain tries to prevent his sister from helping the villagers, but she defies him.

On the first day of the match, large numbers of villagers, many from outlying areas, have come to watch the eagerly awaited match. Further, members of the British leadership in India are also present, and the match is umpired by two Britain-based in Kanpur (spelled Cawnpore before 1948).

Captain Russell wins the toss and elects to bat. The British officers make a strong start, and put on more than fifty runs before Lieutenant Smith, Captain Russell's deputy, is run out by Bhura after a mix-up. Goli then quickly follows up by bowling one of the British officers, who are unable to pick up his multiple swings bowling action and repeatedly miss the ball. Captain Russell then attempts to convince the umpires to ban Goli's bowling because of the multiple swinging of the arm, but Elizabeth runs onto the field and points out there is nothing in the laws of cricket that prohibits this, much to her brother's chagrin. However, Captain Russell detects that Goli grunts immediately before releasing the ball, allowing the officers to detect his deliveries. After that, Russell and his partner easily dispatch his bowling.

Bhuvan brings on his trump card Kachra, who has been spinning his leg break significantly during practice. However, Kachra's spin deserts him and he concedes a lot of runs. During the first day, Lakha, the Indians' best fielder, deliberately drops many catches and at the end of play, the British batsmen are in a strong position. That night, Elizabeth sees Lakha travelling to the British camp to meet her brother and she informs Bhuvan. The villagers attempt to kill Lakha on the spot but Bhuvan offers Lakha one last chance. The next day, the British continue to play with ease against the Indians, and are only three wickets with almost 300 runs, at the lunch break, with Russell confidently predicting to his superiors that they will reach 600. However, Lakha takes a diving one-handed catch which sparks the British batting collapse. Kachra is brought back to bowl, and rediscovers his ability to spin the ball and takes a hat trick, bowling one of the officers around his legs with a leg break that spun more than a metre. Captain Russell reaches his century before being dismissed by Bhuvan, who gives him a send-off. The eccentric village mystic, Guran, gets in on the act. After one batsman repeatedly charges many metres out of the crease to hit his balls, he deliberately bowls a full toss many metres over the batsman's head, stumping the batsman. The officers are bowled out after losing their last seven wickets for less than fifty runs.

The Indians start the run chase strongly, with Bhuvan and Deva Singh Sodhi, a former Sikh sepoy, opening the batting. However, a straight drive from Bhuvan deflects off the hands of Lieutenant Smith, the bowler, onto the stumps, with Deva backing up too far and being run out. The Indians then lose a sequence of quick wickets. When Lakha comes into bat, Russell orders his fastest bowler Yardley to knock Lakha's head off. Yardley then bowls a beamer which hits Lakha directly 
in the temple. Lakha is concussed and falls onto the stumps and is given out hit wicket anyway. Guran briefly launches a counter-attack which his unusual repertoire of shots, while engaging in sledging against the bowlers. Eventually he is dismissed and then the team suffers another injury when Ishmail is forced to retire hurt after being struck on the foot by a yorker. At the ends of the day's play, more than half the team is out and the team has scored less than half of the required runs.

The final day starts well for the Indians, with Bhuvan and the wicket keeper Ishwar batting steadily. However, the Ishwar begins to tire, and is run out after trying to run for an extra run. Bhuvan blames himself for pushing Ishwar's fitness too hard, and Ismail returns to the crease after the umpires allow the village boy Tipu to act as a runner. Bhuvan passes his century and Ismail his fifty as the Indians seize control of the match. However, Smith has another trick up his sleeve and as he is about to bowl to Bhuvan, he stops. The unsuspecting Tipu continues walking out of his crease and is run out. As a result, the match turned again, with runs still needed, and the last batsman to enter the crease is Kachra, whose disability means he cannot hold the bat properly. However, the English bowlers manage to repeatedly miss the stumps while Bhuvan continues to score. The match comes down to the last over. Bhuvan is struck on the head with a bouncer and eventually, Kachra needs to strike a six out of playing arena from the last ball of the match. With his disability, he can only knock the ball away a short distance and the Indians manage only a single.

Bhuvan and the Indian camp are distraught, while the British are jubilant. Nobody however, has heard the umpire signal no ball. Thus, Yardley has bowl the last ball again. Bhuvan swings extremely hard with a pull shot that goes very high up into the air off a top edge. Captain Russell backpedals at long on, and the ball finally descends into his hands after an eternity and Bhuvan is caught.

He then turns around to the British officials sitting under the marquee, and roars in celebration, while the whole stadium is still silent, yet to comprehend what have happened. The British contingent are unimpressed by Russell's antics, and when he looks down at his feet, he finally realises that he has backpedalled too far and caught the ball beyond the boundary of the playing area. Bhuvan's shot has scored six runs, securing a one wicket win for the Indians. The crowd then spontaneously erupts and invades the field, chairing Bhuvan off the field. Suddenly, dark clouds form out of a hitherto cloudless sky, and the drought breaks. After the match, the British high command orders that the cantonment at Champaner be disbanded in humiliation at losing to the Indians.

\section{Memorable quotes from within the movie}

\section{Quote in Hindi}

"Tumhaar khopdi ghoom gayi hai, Bhuwan? ... Khud toh dubogey, hum sab ka laikae dubogey!"

\section{Translation}

Have you gone crazy, Bhuvan? Not only you, we will all be ruined.

\section{Note}

Head of the village to

Bhuvan when faced with the prospect of the cricket match 
"Ha Arjan, Hum sapna dekhat hai. Aur sapna wohi sakaar kar pawai hai, jo unhe dekhat hai."

"Jo hai tumre man mai, Wohi hamre man main. Jo Sapna hai tumra, sapna wahi humre hai jeevan mai"
Yes, Arjan, I dream. For only those who can dream can make their dreams come true

What's in your heart is in my heart too. The dream you have is also my dream in life.
Bhuvan to Arjan during an altercation

An excerpt from a song.

\section{Rang De Basanti, A Revolutionary, Nationalistic and Rebellious Movie}

Rang De Basanti won awards in Best Movie, Best Director, Best Music Director, Critics Best Performance - Male (Aamir Khan), Best Editing (P. S. Bharathi), Best Cinematography and RD Burman Award for New Music (Naresh Iyer) categories. It also won the 2007 International Indian Film Academy awards for the Best Movie, Best Supporting Actress (Soha Ali Khan), Best Screenplay (Rensil D'Silva and Rakeysh Mehra) and Best Music among other technical awards. Apart from these, the film won eight awards apiece at the 2006 Global Indian Film Awards and 2007 Star Screen Awards, and six at the 2007 Zee Cine Awards.

Struggling British filmmaker Sue McKinley (Alice Patten) comes to India after reading the diary of her grandfather, Mr. McKinley (Steven Mackintosh), who served as a jailer in the British Army during the Indian independence movement. She plans to make a short film about some revolutionaries of the independence movement, based on the written account of her grandfather. Her friend, Sonia (Soha Ali Khan), helps her find four young men to act in the film: Daljit "DJ" (Aamir Khan), Karan Singhania (Siddharth), Aslam (Kunal Kapoor) and Sukhi (Sharman Joshi).

They are not enthusiastic at the idea of acting in a film about the independence movement, but Sue wins them over. Laxman Pandey (Atul Kulkarni), a right-wing political party activist, later joins the group, although he is initially unpopular due to his Hindutva beliefs and contempt for Aslam, a Muslim. In the process of filming, the idealism of India's revolutionary heroes' seeps into the protagonists. They gradually begin to realize that their own lives are not very different from the characters they portray on the screen and that the same state of affairs that once plagued the revolutionaries continues to torment the present generation.

While filming, Ajay Singh Rathod (Madhavan), Sonia's fiancé and a Flight Lieutenant in the Indian Air Force, is killed when his plane crashes. The government proclaims that the crash was caused by pilot error and closes the investigation. Knowing that Ajay was an ace pilot, Sonia and her friends do not accept the official explanation. Instead, they claim that he sacrificed his life to save hundreds of other lives which would have been lost had he ejected from the aircraft and left the plane to crash into an overcrowded area. They investigate and learn that the crash was due to a corrupt Defence Minister (Mohan Agashe), who had signed a contract exchanging cheap and illegal MiG-21 aircraft spare parts for a personal favour. 
To their surprise, they also learn that the key person who was responsible for affecting this deal was Karan's father, Rajnath Singhania (Anupam Kher).

Discontent with the situation, the group and their supporters decide to protest peacefully at India Gate, a war memorial in New Delhi, India. Police forcefully breaks up their protest and in the process; Rathod's mother (Waheeda Rehman) is severely hurt. These young men decide that they must emulate the early freedom fighters and resort to violence to achieve justice. They kill the Defence Minister to avenge Rathod's death. The minister is speculated to have been killed by terrorists and is hailed as a martyr by the media. To bring forth the true story, the group decides to go public through a radio station. Before they do so, Karan murders his father for his corrupt actions. DJ, Sukhi, Karan, Pandey and Aslam forcibly take over the All India Radio station premises. Karan goes on air and reveals the truth about the Defence Minister and his wrongdoings. While still on the air, they are all killed in an ambush by the police and commandos.

Zindgi jeene ke sirf do tariqa hote hain - Ek, jo ho raha hai hone do, bardaasht karte jaao; Ya phir zimmedaari uthaao use badalne ki (Translation: There are only two ways to live life - Tolerate things the way they are; Or take responsibility to change them).

One of Prasoon Joshi's dialogues in the film that brought him an award nomination. Furthermore, this quote carries the central message of the film.

\section{Taare Zameen Par, An Inspirational, Experimental and Directorial Movie}

Critically acclaimed, Taare Zameen Par won the 2008 Filmfare Best Movie Award as well as a number of other Filmfare and Star Screen Awards. It was declared tax free by the then Government of Delhi. Furthermore, Taare Zameen Par won several awards in major cinema award ceremonies in India, including a number of Filmfare Awards and Star Screen Awards. However, it was not submitted for consideration to the IIFA.

Ishaan Nandakishore Awasthi (Darsheel Safary) is an eight-year old boy who hates school. Every subject is difficult for him and he perpetually fails his exams. He also lacks motor coordination skills and finds it difficult to throw a ball in a straight line. Rather than helping him, his teachers and classmates subject him to constant acts of public humiliation. At the same time, Ishaan's internal world is rich with wonders that no one else seems to appreciate: magical lands filled with colour and animated animals; letters which morph into an advancing army of spiders; and adventures in space between the battling planets 9 and 3 .

It is no better at home. His father (Vipin Sharma) is a successful and busy executive who expects the best from his boys. His mother (Tisca Chopra) happens to be a housewife who is perpetually frustrated by her inability to help Ishaan excel.

Ishaan's elder brother Yohaan (Sachet Engineer) is a successful scholar/athlete, a fact which Ishaan is constantly reminded of. After discovering that Ishaan "bunked" school (in addition to having poor grades), his parents send him to boarding school to be 'disciplined.' 
Life at the boarding school does not help Ishaan to excel, despite being befriended by Rajan (Tanay Cheda). Instead, he sinks into a perpetual state of fear and depression as he now has to contend with the added trauma of separation from his family. This changes, however, when a new temporary art teacher Ram Shankar Nikumbh (Aamir Khan) joins Ishaan's boarding school. Nikumbh, with his characteristic teaching style that is markedly different that his strict predecessor soon becomes popular among the students. He begins to notice that Ishaan is unhappy and a non-contributor to activities in the class (despite creating an atmosphere in the class that actively seeks contribution from the students). Disturbed, Nikumbh begins to review Ishaan's past work and discovers that all of his "failures" are actually reflective of dyslexia.

On his day off, Nikumbh visits Ishaan's parents and asks to review more of his work. He is also stunned by the sophistication of Ishaan's paintings. Nikumbh tells Ishaan's parents that Ishaan is a bright child who processes information differently than the other children in clas s. He describes dyslexia to them and clarifies that this is a neurological condition which is not a sign of low intelligence. He also tells them he can provide extra tutoring which will help Ishaan succeed. To support this argument, Nikumbh highlights Ishaan's artistic ability as demonstrated by his many paintings and creative works-of-art. In order to make his point, Nikumbh demands that Ishaan's father read a box with Japanese text. When Mr. Awasthi states that he cannot read the text, Nikhumbh reprimands him. In doing so, Nikhumbh demonstrates to them what Ishaan struggles with on a daily basis. When he returns to the school, Nikumbh brings up the topic of dyslexia one day in class and offers a list of famous people who are considered dyslexic: Albert Einstein, Leonardo Da Vinci, Walt Disney, Agatha Christie, Thomas Edison, Pablo Picasso, and actor Abhishek Bachchan. As the students are leaving the classroom Nikumbh asks Ishaan to stay back. At that time Nikumbh reveals that he has experienced the same difficulties with dyslexia. Next, Nikumbh conveys the same information to the principal of the school and asks if he can act as a tutor for Ishaan. After gaining the Principal's assent, Nikumbh takes it upon himself to develop and improve Ishaan's reading and writing abilities. Nikumbh then proceeds to teach Ishaan using remedial techniques developed by specialists in the area of dyslexia. Ishaan soon develops interest in language and mathematical skills and his grades improve. Next, Nikumbh organizes an art fair for staff and students alike. The competition is judged by Lalita Lajmi (who portrays herself in the movie). Ishaan, with his strikingly creative style is declared the winner, while his teacher, Nikumbh (who paints Ishaan's portrait) is declared the runner up.

At the end of the year, when Ishaan's parents meet the teachers, they are speechless to see the change in Ishaan. Ishaan has improved in all of his subjects and has a commendable grade in painting. Ishaan's father breaks into tears upon seeing this change and realizes his past mistakes. Before leaving for the holidays, Ishaan runs to hug his teacher who jubilantly tosses him in the air.

\section{Conclusion and Suggestions}

Aamir Khan appears to be a multi-dimensional, multi-coloured, and multi-faceted film star, who casts a spell on each and every lover of Indian cinema. Really speaking, he may be rightly described as a megastar, actor, producer, and director. And above all, Aamir Khan has been 
permanently carved out a unique niche in commercial Hindi cinema. He seems to have been acknowledged as a patriarch of Bollywood. He is an extraordinary versatile actor of India's film making industry. He is also known as a perfectionist, lover, idealist, activist, social worker, and reformer. Aamir Khan has also been a controversial figure. Though, his films always evoke extreme reactions, he knows that mass audience has made him, he never deserted them, yet some critics always deny to embrace the fabulous personality.

Sensitivity, perception and cinematic subtlety; when Aamir Khan represents his characters on celluloid, all this and much more redundantly scattered here and there. The music of Aamir Khan's movies has also achieved phenomenal success across the nation. The musical sense, feel of rhythm and involvement in music settings have ensured the highest quality of music in his films.

Aamir Khan epitomized the qualities of innovation, change, discovery, self-expression and excellence in performance on the screen when it comes to perform and depic his characters in the movies like Lagaan, Rang De Basanti and Taare Zameen Par.

In an industry where every film is promoted as a product, Aamir Khan stands unmatched. One does always expect freshness in the character of an actor and he fulfil the same on the celluloid. We are living in a world where instant gratification is supposed to be accepted the norm, but Aamir Khan is always concerned to protect the core values of real life even in reel life. Most of his movies have had a telling impact on cinemagoers' hearts and minds, whether it is the candlelight vigils that began after Ran De Basanti or the debate on how we teach our children set off by Taare Zameen par. Whereas, in Lagaan, the team of mavericks laboured to improve their performance under the gaze of an unforgiving man, Bhuvan. The underdog team came from behind to clinch like a well-strategised victory against the dogmatic English men.

The common garden variety movie stars become popular because of their sex appeal at an individual level. But Khan is very much like the great Bollywood actor-directors of the 1950s. In clique-ridden Bollywood his status is unique. He's the outsider who's the ultimate insider because his success is both creative and commercial.

Most of his films sparked a mini-movement. Aamir Khan, the non-conformist actor, has become Bollywood's favourite mass entertainer with a message. Aamir Khan has created the situations to explore social issues and complex human relationship. And, when the same projected on a 70-mm screen with Dolby effects, they can seep into our spell-bound minds with an easy comfort.

The viewer is indeed giving the thumbs up to movies where reality mixes readily with humour and entertainment, where the dark, deep, gore and gloom are tempered to reduce their shock quotient, and where all is not always lost, vanquished or relinquished. Undoubtedly, it is Aamir Khan who is devoted to fulfil the very needs and requirements of the viewers. Take, for instance, Lagaan, Rang De Basanti, Taare Zameen Par, which scored a goal with cine buffs because of its realistic approach.

As far as thematic treatment is concerned, Aamir Khan's movies go beyond the limit to touch the sky and better the down-trodden set up pattern of the society. Both, as an actor and a filmmaker, he seems to retain romantic optimism and secularism in his movies. 
Aamir Khan's ideology is basically a mixture of love, whether it may be dangerous or safer. Thus, Aamir Khan's rebel is never an outsider, he is the man who always wants to fight against the contours of evil, projected in his Bollywood's movies. It is the very young optimist who firstly prepared a cricket team of mavericks and ultimately defeats the English to teach them a lesson or two in his movie Lagaan. It is the imperishable bloom of optimism, romanticism and a child-like innocence that has been the hallmark of Aamir Khan's films among our decades of film lore. That is the reason he never drums up hyper-nationalist rhetoric in his movies.

Aamir Khan always intends to work within the cinematic tradition he inherited, with a difference. He successfully infuses the patriotic sense and sensibility with a splendid blend of romantic temperament in his movies. From this point of view, he is completely at ease whether it is script or dialogue, photography, lighting, sound, recording, editing, picturization of songs, music and cinematic effects, all these is at his fingertips and when he goes to work they blend in a magic crucible to images as superb pictures. Moreover, Aamir Khan's movies are a living testimony of tout editing, good pace and focused narration. Lagan, Rang De Basanti, Taare Zameen Par are the good examples as a proof. He is imperious and majestic, a dreamer of big dreams.

Irrespective of its genre, an Aamir Khan production is looked forward to with super-enthusiasm. Films like Lagaan, Taare Zameen Par, have redefined cinema and in their own small way prompted fil-makers to think beyond the stereotype. He admits to having consciously worked on all troubled relationships in his life, including with media. "I learnt a lot as a result of Taare Zameen Par; that more changed me and I became even more sensitive to people and their relatives. A psychiatrist I met during research for TZP told me all children need Security, Trust \& Faith, Dignity \& Self-respect and Love. I realized I need the same things and so does everybody around. I decided to apply this learning to all relationships and this is what helped me understand and interact better with media as well."

Suffice to say, despite the ensconced generosity and benign nature, the breakaway faction and opponents have always been in search of negative facts for defamatory reasons against him, but he always come out unscathed. Thus, Aamir Khan is fit to be showered with a lot of adoration in that he has found deep-rooted place into cinemagoers' hearts. In a word, Aamir has an amazingly obsessive personality and he is his own man.

\section{References}

[1] Chaturvedi, A. (2008, July 9). Movies, Aamir, life: Kiran speaks her minds finally. The Times of India.

[2] Bunsha, D. (2006, June 3-16). Frontline.

[3] Rajadhyaksha, A., \& Willemen, P. (1999). Encyclopedia of Indian cinema. London, UK: British Publishers.

[4] Sharma, K., \& Prabhakar, J. (2008, July 12). The Times of India.

[5] Zia-Us-Salam, \& Siddqui, R. (2008, July 11). Living up to Papa's hopes. The Hindu.

*Corresponding author.

E-mail address: afaqmasscom@ gmail.com 